\title{
Utilization of Information and Communication Technology at the Baranti District Office, Sidenreng Rappang Regency
}

\author{
Jamaluddin $^{1}$, Achmad Fahrul Adiguna ${ }^{2}$, Suprianto $^{3}$, Muh. Nasrullah ${ }^{4}$, \\ Sirajuddin Saleh ${ }^{5}$, Ahmad Syaekhu ${ }^{6}$ \\ ${ }^{1,4,5}$ Universitas Negeri Makassar, ${ }^{3}$ Universitas Borneo Tarakan, ${ }^{6}$ Universitas Sawerigading \\ Email: jamaluddin8002@unm.ac.id
}

\begin{abstract}
Utilization of Information and Communication Technology at the Baranti District Office, Sidenreng Rappang Regency. This study aims to determine the use of information and communication technology in the Baranti sub-district office, Sidenreng Rappang district. This research is a descriptive study with a qualitative approach. The main informant is the Head of the District Head Office of Baranti District. Supporting informants consist of the Secretary and Head of General Services. The data collection techniques used were interviews, observation, and documentation. Data analysis techniques used data collection, data reduction, data presentation, and conclusions. The results show that the use of information and communication technology places more emphasis on hardware aspects such as the use of computers in processing data and information and is used to store data and information so that they can be reused, use of telephones to convey information, use printers to convert files into printed form, use a projector to display data that has been processed on the computer. Meanwhile, in terms of processing and sending data using a computer as a tool with E-mail media via the internet network.
\end{abstract}

Keywords: Utilization, technology, information, communication

\section{INTRODUCTION}

Technology libraries in this era are experiencing rapid development. Along with technological advances, it affects many aspects of life, including economics, politics, and education. This technological progress will continue to run following scientific advances, this is something that cannot be avoided (Li et al., 2020; Lukas et al., 2016; van Assen, 2020). Humans make many positive innovations and make it easy to carry out activities. Technological progress is initially created for positive things, but on the other hand, it can also have negative impacts. All of these things can happen depending on who uses them.

Information technology is software and hardware that are interrelated with the processing, storing, and processing of data, voice, and video which are useful for improving the distribution of information to make it more effective and of high quality (Guzmán et al., 2020; Kelemen et al., 2020; Viete \& Erdsiek, 2020). Communication is a process of conveying information through symbolic processes such as words and pictures to achieve certain goals using the help of the media (Kshetri, 2005; Zakaria, 2017). Information and communication technology are all activities that are interrelated with the processing, manipulation, management, transmission of information using the media (Presbitero, 2021; Zakaria, 2017). Or it can also be interpreted that information technology is the delivery of information to others to influence others using the media.

Copyright (C) 2021 Universitas Negeri Makassar. This is an open access article under the CC BY license (http://creativecommons.org/licenses/by/4.0/) 


\section{8 | Jurnal Administrare: Jurnal Pemikiran Ilmiah dan Pendidikan Administrasi Perkantoran \\ Volume 8 Issue 1, January-June 2021. Pages 157-164}

Talking about technology, of course, it cannot be separated from human life (Jordan, 2014; Rezaul Islam et al., 2020; Verbeek, 2008). As long as civilization still exists, technology will continue to develop and become the most important thing in carrying out activities. It is undeniable that today's technology cannot be separated from human life. Starting from small children to adults, and traders to large companies are very dependent on information and communication technology. Information and communication technology includes two aspects, namely aspects of information technology and communication technology. Information technology includes all matters relating to the process, use as a tool, manipulation, and information management. Communication technology is all things related to the user to process and transfer data from one device to another. Information and communication technology are all activities related to the processing, manipulation, management, and transfer of information based on inter-media (Feller et al., 2020; Viete \& Erdsiek, 2020). The transfer of information between media is one of the uses of information and communication technology. This one affects the performance of an agency. The use of information and communication technology must be supported by capable capabilities so that it can improve company performance or individual performance.

\section{METHOD}

This research is descriptive research with a qualitative approach. According to (Arikunto, 2010), what is meant by descriptive research is research that is intended to collect information about the status of an existing symptom, namely the state of the symptoms according to what they were when the research was carried out. And according to (Denzin, Norman \& Lincoln, Yvonna, 2018), qualitative research is research that uses a natural setting to interpret the phenomena that occur and is carried out by involving various existing methods. Data sources or also known as informants are people who will be used to provide information about the situation and conditions of the research environment. The main data sources in this research are words and actions. The rest is such as through written notes, recordings, photos, documents, and others. Sources of data from this study consisted of the Head of the Baranti sub-district office, the secretary of the sub-district head, and employees. The data collection techniques used were interviews, observation, and documentation. Meanwhile, data analysis was carried out through four stages, namely data collection, data reduction, data presentation, and conclusion drawing.

\section{RESULT AND DISCUSSION}

To find out how the information and communication technology utilization at the Baranti District Office, Sidenreng Rappang Regency, is carried out processing and presenting the data that has been obtained by the researcher during the research which is then adjusted to the grand theory used by the researcher, namely, the theory put forward by Darmawan in (Praditya, 2014) regarding indicators consisting of: improve efficiency, improve services, help achieve a certain policy, help contribute to economic policy, increase contribution to reform, increase trust between the government and its people. The descriptions of the results of the research data analysis conducted at the Baranti District office are as follows: 


\section{Increase Efficiency}

Efficiency is a measure of the success of an activity that is assessed based on the number of costs or resources incurred to achieve planned results. In this case, the fewer costs or resources used to achieve an expected result, it can be said to be efficient. To increase efficiency in government offices, information and communication technology is used. In the sub-district office, Baranti itself has used technology and information as a means to achieve this efficiency.

Information and communication technology can improve efficiency in sharing data or information within and between governments. The use of information and communication technology itself in its use can also increase efficiency in data collection, data delivery, information provision, and communication. Likewise in processing duties and processes of public administration.

\section{Improve Service}

Service is defined as all forms of activities carried out to provide satisfaction to customers or people in need, either in the form of goods or services which are the responsibility of and implemented by government agencies. The use of information and communication technology can improve services to the community. In using public services, people do not need to know the complex structures and relationships provided by the government.

\section{Help Achieve a Specific Policy}

Information and communication technology can help achieve a certain policy, it can be interpreted that information and communication technology helps stakeholders, namely the government in sharing information and ideas, to then contribute in determining policy results. For example, information can encourage the use of training and education programs as well as the process of sharing information between central and local governments. Information and communication technology can also assist in disseminating government policies to the public so that related parties can share information and ideas with a particular policy. By using information and communication technology, delivery to the public can be more effective and efficient, for example using a projector in a community meeting to present policies or data to the public.

\section{Help Contribute to Economic Policy}

The use of information and communication technology in government can reduce corruption, increase public openness and trust in the government and the government with the government itself and contribute to the economic policy itself. Specific impacts include a reduction in government spending through more effective programs, efficiency, and increased business productivity through simplification of administration made possible by information technology and improvements in government information.

When viewed from the use of information and communication technology in this office, it can be said that it is sufficient to reduce costs and service is also fast. Information and communication technology can increase trust between the public and the government because of this. So information and communication technology is a medium of liaison between government and society. Information and communication technology has not been used very much when it 
comes to the openness of the government to the public, because the Baranti sub-district office does not yet have its website to show information to the public. However, information about the Baranti sub-district can be seen on the regency website, although it is not very comprehensive.

The government is transparent about what news or information is validated through the media. Of course, that is one example that can justify that the government and society can communicate with the government through technology and information. but in fact, this office has not been able to do that.

\section{Increase Contribution to Reform}

Reform in government is defined as a change in a system that has existed during a period. Reform is aimed at realizing good governance which in its implementation will be more effective and efficient. The use of information and communication technology has changed or reformed various fields such as improving transparency and information sharing facilities.

Information and communication technology has changed or reformed various fields. The government is now facing the issue of modernization and public management reform. Current developments mean that the reform process must be sustainable. Information and communication technology has been reformed by increasing transparency and facilitating the sharing of information.

Information and communication technology has a role, namely being able to transparent or eliminate corrupt practices in the presence of information disclosure to the public. As before, this information can be seen on the regency's official website because the Baranti District office does not yet have an official website. With the existence of information and communication technology, the relationship with the community can be well established because the services provided are quite fast.

\section{Increase the Trust Between the Government and its People}

Building trust between government and society is fundamental to good government. Information and communication technology can help build government trust by enabling public involvement in the policy process, promoting open and accountable government, and helping to prevent corruption. If the aspirations and opinions of the public can be facilitated or accommodated in information and communication technology-based media, it can increase public confidence in the government.

Information and communication technology can improve good governance by increasing transparency, reducing corruption to increase public trust in government officials. Building trust between government and society is fundamental to good governance. Information and communication technology can help build trust by enabling public involvement in the policy process, promoting open and accountable government, and helping to prevent acts of corruption. In addition, if limitations and challenges are properly addressed, e-government can help bring the voice of the people to a wider debate. This process is carried out by utilizing information and communication technology to encourage the public to be able to build on public issues and assess the impact of applying technology to open up the policy process 
Jamaluddin, et al.; Utilization of Information and Communication Technology ...| 161

\section{DISCUSSION}

\section{Increase Efficiency}

Information and communication technology can improve efficiency in sharing data or information within and between governments. The use of information and communication technology itself in its use can also increase efficiency in data collection, data delivery, information provision, and communication. Likewise in processing duties and processes of public administration.

Based on the results of data analysis, efficiency is a measure of the success of an activity which is assessed based on the number of costs or resources incurred to achieve the planned results. In this case, information and communication technology has a very important role in completing work at the Baranti District office. With technology, the management of administrative files at the Baranti District office can run efficiently, this is because the technology used can support the easy management of identity cards, family cards, and so on. In making efficient use of information and communication technology, data collection was previously done by writing one by one or with a typewriter, so it took a long time. But now because of technological advances, the use of computers or laptops greatly affects the time to do work at the Baranti District office. The results of this study are also in line with the opinion of experts namely Praditya (2014) who views "one of the uses of information and communication technology, namely increasing efficiency".

\section{Improve Service}

Service is defined as all forms of activities carried out to provide satisfaction to customers or people in need, either in the form of goods or services which are the responsibility of and implemented by government agencies. In improving services in government agencies, especially in the Baranti District office, the growing information and communication technology is used to support administrative services so that people's needs can be met without requiring a long time.

Based on the results of the analysis above, in improving service, of course, we need technologies that support the ease of service. Such as computers, laptops, and cellphones which are used as tools that can help in serving the community. These tools can be used in remote file management (online) in managing identity cards, family cards, and so on. Thus in improving a technology service has an important role. In improving services by using information and communication technology, such as the provision of information dissemination through the media for those located far from the office, access to information is easier to find. For example, by utilizing social media such as WhatsApp and email using cellphones, laptops, or computers.

In a meeting held at the subdistrict office hall. Employees can use the projector to display important things that want to be conveyed to the public and display images or videos, as well as additional explanations after video viewing. This is useful so that the public can grasp the important points conveyed.

The results of this study are also in line with the opinion of Sinambela (2011) which states that "service is an activity or sequence of activities that occur indirect interaction between a person and another person or a physical machine, and provides customer satisfaction". Of course, this is closely related to improving service, one of which is customer satisfaction. 


\section{Help Achieve a Specific Policy}

Information and communication technology can help stakeholders share information and ideas and then contribute to determining policy outcomes. And information technology can also assist in disseminating policies that have been determined by the government to the public so that related parties can share ideas and information related to the policy.

Based on the results of data analysis, it can be concluded that the use of information and communication technology at the Baranti District office has not been maximized because it is constrained by the absence of an official website belonging to the Baranti District office. This is because there are no capable employees in this field. Related to this, the government cannot show openness to society. But behind this, information and communication technology can still increase public trust in the government because this information and communication technology can make administrative services more efficient.

The results of this study are in line with the Islamic opinion in Sholih Muadi (2016) "policy is a guideline for action proposed by a person, group or government in a certain environment by showing the obstacles and opportunities for implementing the proposed policy to achieve the goal. certain". Of course, this is related to helping to achieve a policy, it is a very much needed suggestion in determining policy.

\section{Help Contribute to Economic Policy}

The use of information and communication technology in government can reduce corruption, increase public openness and trust in the government and the government with the government itself and contribute to the economic policy itself. Specific impacts include a reduction in government spending through more effective programs, efficiency, and increased business productivity through simplification of administration made possible by information technology and improvements in government information.

Based on the results of data analysis, it can be concluded that the use of information and communication technology at the Baranti District office has not been maximized because it is constrained by the absence of an official website belonging to the Baranti District office. This is because there are no capable employees in this field. Related to this, the government cannot show openness to society. But behind this, information and communication technology can still increase public trust in the government because this information and communication technology can make administrative services more efficient. The results of this study are in line with the opinion of Praditya (2014) which states that "in the use of government information and communication technology, one of which includes: a. Helping to contribute to economic policy".

\section{Increase Contribution to Reform}

Reform in government is defined as a change in a system that has existed during a period. Reform is aimed at realizing good governance which in its implementation will be more effective and efficient. The use of information and communication technology has changed or reformed various fields such as improving transparency and information sharing facilities. From the results of the analysis, information and communication technology can change or reform 
various areas such as improving transparency and information sharing facilities. However, the Baranti District office has not been able to take advantage of information and communication technology in this field. Because there is no official website itself, but information about the Baranti District office can be seen on the official website belonging to the Sidenreng Rappang district. The results of this study are in line with the opinion of Sinambela (2014) that "reform is a change where the depth is limited, while the flexibility to change also involves the entire community". Of course, this is related to increasing the contribution to reform because in the contribution of course there must be changes and also involve all elements.

\section{Increase the Trust Between the Government and its People}

Building trust between government and society is fundamental to good government. Information and communication technology can help build government trust by enabling public involvement in the policy process, promoting open and accountable government, and helping to prevent corruption. If the aspirations and opinions of the public can be facilitated or accommodated in information and communication technology-based media, it can increase public confidence in the government.

Based on the results of data analysis, information and communication technology in its use can improve good governance through increased transparency, reduce corruption to increase public trust with the government. The Baranti sub-district office itself does not yet have an official website that can make information transparent. Because there are no employees who can create and manage websites, the Baranti sub-district office needs employees who are competent in this field. The results of this study are also in line with the opinion of J.S Badudu in Kurniawati, (2017) said that "utilization is the thing, the way, the result of the work in utilizing something useful. Making use of something useful is a form of utilization. " Of course this is in line with increasing trust between the government and the public because if a work result is useless it cannot be said that it is useful, something useful will greatly increase public trust in the government.

\section{CONCLUSION}

Based on the results of research on the use of information and communication technology at the Baranti District office, Sidenreng Rappang Regency, it can be concluded that the use of information and communication technology at the Baranti District office emphasizes the hardware aspects such as by using computers in processing data and information and is used for store data and information for reuse, use the telephone to convey information, use a printer to convert files into printed form, use a projector to display data that has been processed on a computer. Meanwhile, in terms of processing and sending data, the Baranti District office uses a computer as a tool with E-mail media via the internet network.

\section{REFERENCES}

Arikunto, S. (2010). Prosedur Penelitian Ilmiah. In Rineka cipta, Jakarta.

Denzin, Norman, K., \& Lincoln, Yvonna, S. (2018). Introduction: The Discipline and Practice of Qualitative Research. In The Sage Handbook of Qualitative Research.

Feller, D. J., Lor, M., Zucker, J., Yin, M. T., Olender, S., Ferris, D. C., Elhadad, N., \& 
164 | Jurnal Administrare: Jurnal Pemikiran Ilmiah dan Pendidikan Administrasi Perkantoran Volume 8 Issue 1, January-June 2021. Pages 157-164

Mamykina, L. (2020). An investigation of the information technology needs associated with delivering chronic disease care to large clinical populations. International Journal of Medical Informatics, 137 104099. https://doi.org/https://doi.org/10.1016/j.ijmedinf.2020.104099

Guzmán, V. E., Muschard, B., Gerolamo, M., Kohl, H., \& Rozenfeld, H. (2020). Characteristics and Skills of Leadership in the Context of Industry 4.0. Procedia Manufacturing, 43, 543550. https://doi.org/https://doi.org/10.1016/j.promfg.2020.02.167

Jordan, P. D. (2014). Technology as human social tradition. University of California Press.

Kelemen, T. K., Matthews, S. H., \& Breevaart, K. (2020). Leading day-to-day: A review of the daily causes and consequences of leadership behaviors. The Leadership Quarterly, 31(1), 101344. https://doi.org/https://doi.org/10.1016/j.leaqua.2019.101344

Kshetri, N. (2005). Information and communications technologies, strategic asymmetry and national security. Journal of International Management, 11(4), 563-580. https://doi.org/https://doi.org/10.1016/j.intman.2005.09.010

Kurniawati, D. (2017). Pemanfaatan teknologi informasi dan komunikasi oleh perangkat desa Gandulan Kecamatan Kaloran Kabupaten Temanggung. Universitas Negeri Yogyakarta.

Li, C. Z., Zhao, Y., Xiao, B., Yu, B., Tam, V. W. Y., Chen, Z., \& Ya, Y. (2020). Research trend of the application of information technologies in construction and demolition waste management. Journal of Cleaner Production, 263, 121458. https://doi.org/https://doi.org/10.1016/j.jclepro.2020.121458

Lukas, S., Mitra, A. R., Desanti, R. I., \& Krisnadi, D. (2016). Student attendance system in classroom using face recognition technique. 2016 International Conference on Information and Communication Technology Convergence (ICTC), 1032-1035.

Praditya, D. (2014). Pemanfaatan Teknologi informasi dan Komunikasi (TIK). 88, 129-140.

Presbitero, A. (2021). Communication accommodation within global virtual team: The influence of cultural intelligence and the impact on interpersonal process effectiveness. $\begin{array}{llll}\text { Journal of International } & \text { Management, } & \text { 27(1), } & 100809 .\end{array}$ https://doi.org/https://doi.org/10.1016/j.intman.2020.100809

Rezaul Islam, M., Wahab, H. A., \& Anggum, L. ak. (2020). The influence of leadership quality towards community cohesion in Iban community in Malaysia. Heliyon, 6(2), e03370. https://doi.org/https://doi.org/10.1016/j.heliyon.2020.e03370

van Assen, M. F. (2020). Empowering leadership and contextual ambidexterity - The mediating role of committed leadership for continuous improvement. European Management Journal, 38(3), 435-449. https://doi.org/https://doi.org/10.1016/j.emj.2019.12.002

Verbeek, P.-P. (2008). Cyborg intentionality: Rethinking the phenomenology of humantechnology relations. Phenomenology and the Cognitive Sciences, 7(3), 387-395.

Viete, S., \& Erdsiek, D. (2020). Mobile Information Technologies and Firm Performance: The Role of Employee Autonomy. Information Economics and Policy, 51, 100863. https://doi.org/https://doi.org/10.1016/j.infoecopol.2020.100863

Zakaria, N. (2017). Emergent Patterns of Switching Behaviors and Intercultural Communication Styles of Global Virtual Teams During Distributed Decision Making. Journal of International Management, 23(4), 350-366. https://doi.org/https://doi.org/10.1016/j.intman.2016.09.002 